\title{
Effects of different planting systems on yield of potato crop in Kaghan Valley: A mountainous region of Pakistan
}

\author{
Muhammad Qasim $^{1 *}$, Salma Khalid ${ }^{1}$, Alia Naz ${ }^{1}$, Muhammad Zafarullah Khan $^{2}$, \\ Sohail Ahmad Khan ${ }^{2}$ \\ ${ }^{1}$ Department of Environmental Sciences, Abdul Wali Khan University Mardan, Mardan, Pakistan; \\ *Corresponding Author: drqasim@awkum.edu.pk \\ ${ }^{2}$ Department of Agriculture Extension and Communication, Agricultural University Peshawar, Peshawar, Pakistan
}

Received 1 March 2013; revised 5 April 2013; accepted 20 April 2013

Copyright (C) 2013 Muhammad Qasim et al. This is an open access article distributed under the Creative Commons Attribution License, which permits unrestricted use, distribution, and reproduction in any medium, provided the original work is properly cited.

\begin{abstract}
Conversion of potato from conventional methods to wide bed planting systems may increase water and nitrogen use efficiency in commercial potato production system by reducing the amount of irrigation water and water applied nitrogen fertilizer bypassing the potato root zone. Potato (Solanum tuberosum L) cv. Desiree was tested against different planting system for yield and yield components at Kaghan, a high mountainous Himalayan region of Pakistan. The experiment was carried out at Himalayan Agricultural Research Station (HARS), Kaghan during the summer season of 2005. The results showed that maximum tuber growth (88.7\%), number of stems per plant (3.5), plant expansion $(45.5 \mathrm{~cm})$, average number of tubers per plant (10.1) and yield per hectare (12.4 t/ha) were significantly different and higher when potatoes were planted on wide bed and covered with soil from one side. Tallest plants $(53.4 \mathrm{~cm})$ were observed when potatoes were sown on the ridges. Maximum number of green potatoes (12.5) and injured potatoes $(5.3 \%)$ were observed when the tubers were planted following local farmers' method. Keeping in view the soil type, land slopping, we recommend sowing potatoes on relatively plain wide beds and covering it with soil from one side, for potato cultivation in the area.
\end{abstract}

Keywords: Potato (Solanum tuberosum L); Planting Systems; Yield Response; Kaghan Valley; Pakistan

\section{INTRODUCTION}

In the Indo-Pak sub-continent, the potato was introduced by the Portuguese. However, its cultivation was encouraged by the British in the 19th century. In the earlier days it was grown in botanical gardens as a curiosity plant and the potato tubers were exhibited in the horticultural shows organized in big towns. Later on, it was accepted as vegetable. It is considered as important vegetable at present also and is generally called as "King of vegetables" in Pakistan.

Potato (Solanum tuberosum L) is an annual, herbaceous, tuber crop of family Solanaceae that contains all the essential food ingredients required for main- taining proper health. Potato is the world's leading vegetable crop and is grown in $79 \%$ of the world's countries [1]. It is second to maize in terms of the number of producing countries and fourth after wheat, maize and rice in global tonnage. The average composition of the potato is about $80 \%$ water, $2 \%$ protein, and $18 \%$ starch. As a food, it is one of the cheapest and easily available sources of carbohydrates and proteins and contains appreciable amount of vitamins B and C as well as some minerals. Moreover, protein of potato is of high biological value [2,3]. In one form or another, there can hardly be any table in the world, where this vegetable is not served as a food item [4,5]. Potato is becoming increasingly important crop, as it is staple food in most of the European countries and is a good and cheap source of food calories and its high starch content can meet the energy requirements of the people living in food deficit countries [6,7]. Accredited to its short duration, nutritional superiority and high amount of food per unit area and time, potato production in developing countries has been increased by about $25 \%$ over the last 4 decades. 
Potato is basically a cool season crop in origin and has been grown traditionally under conditions that prevail in the northern latitudes of Europe and America and in tropical highlands such as the Andean region in South America and or the Himalayan, Karakorum, Hindu Kush valleys of the indo Pak subcontinent. Now potato is successfully grown in tropical, sub-tropical and temperate climate and is adapted to diverse socio-economic conditions. Potato farming systems in Pakistan are comparatively complex and diverse because of variability in climate, socioeconomic, cultural and agronomic conditions. Pakistan is divided into eight agro ecological zones for potato production on the basis of altitude, longitude, latitude, topography, climate, soil and irrigation $[8,9]$. Three crops, autumn, spring and summer crops of potatoes are being cultivated in Pakistan. In the plains of Punjab and Khyber Pakhtunkhwa, generally two crops are raised in a year i.e., autumn and spring crops while a third one is cultivated in the hilly areas of KPK during the summer season. Different planting methods are used for potatoes in different potato growing areas. In hilly area like Kaghan potatoes are sown haphazard without any specified distance between the tubers. In the plains of KPK potatoes are planted on ridges spaced approximately $25 \mathrm{~cm}$ apart; the distance between ridges is kept about $75 \mathrm{~cm}$. In Pakistan potato is grown on a large area. The northern area of the Pakistan is the main seed producing area and supply seed to the rest of the country. Potato is the one of the major source of income in northern areas where farmers are poor and most of them have very small land holding ranging from 0.25 to 1.0 ha. Almost all the members of the family are involved for providing labor force for land preparation, planting, digging and harvesting. It is the most profitable crop and grown year after year. Potato cultivation in Pakistan is easily being incorporated into multiple cropping systems. It is intercropped with Fennel (Foeniculum vulgare), mustard (Brassica spp) and eggplant (Solanum melongena) in the southern plains of Sindh; planted as a relay with sugarcane in the Peshawar valley and cultivated as a missed crop with maize and beans in the Kalam and Chitral valleys [10].

At the time of independence in 1947 the area under potato crop was 3000 hectare which increased to 145,000 hectare during 2008-2009 and the total production increased from 15,000 tons to 2,941,300 tons during the same period. This shows that potato production in Pakistan has increased many folds but it's per hectare yield is far less as compared to other parts of the world [11,12]. There are various factors responsible for low production. The main reason for low productivity of potato in Pakistan may be due to non-availability of healthy and certified seed, high yielding varieties, poor agronomic and management practices and ineffective land utilization.
Within the present resources use of good quality certified seeds of best-suited variety and effective land utilization are the easiest ways to increase the yield $[8,13,14]$.

Reference [15] observed that vines of sweet potatoes cv. Kamalasundari and Triti planted in $20 \mathrm{~cm}$ deep furrows and or on ridges of $15 \mathrm{~cm}$ height with water hyacinth. They harvested the highest tuber yield of $14.37 \mathrm{~kg}$ from cv. Kamalasundari planted in furrows and mulched. Reference [16] demonstrated a trail of potatoes cv. Irish Cobbler planted 5 - 7 or 12 - $15 \mathrm{~cm}$ deep in single row. According to him the total yields at 90 or 100 days after planting did not differ significantly but the proportion of green tubers significantly increased with double rows. The lowest labour requirement was with deep planting and double rows because no earthing-up was required. Reference [17] evaluated direct planting of potatoes in soil remained moisture which remained colder throughout the growing period. He found his plants with lowest growth, late ripening/maturing. Development of the tubers was delayed and they continued to grow for longer. Yields for direct planting were early in the season and higher at later dates. Reference [18] found that potatoes grown on a flat seed beds, mounds (semi ridges) and ridges gave average tuber yields of 30.39, 32.09 and $31.53 \mathrm{t} / \mathrm{ha}$, respectively. Reference [19] compared survival of potato tuber sprouts of cultivars Kufri Chandramukhi and Kufri Jyoti and noted that their yield potential were significantly better when planted on East, West and South sides of the ridge than on the North side. References [20,21] studied potatoes cv. Kufri Lalima planted in ridges or flat seed bed and reported that there was no significant difference between planting methods. Reference [22] demonstrated that in field traits on sandy loam soils potato cv. Kufri Sindhur planted on ridge and furrow methods. Tuber yield was highest with the ridge method. Looking at the importance based on the literature cited above, we therefore conducted the experiment to find the best planting method for the high and quality potato yield in Kaghan valley.

\section{METHODS}

This study was conducted at Himalayan Agricultural Research Station, Kaghan during the summer season of 2005. Potato cultivar Desiree was planted with the following five different planting methods,

- Local farmer's planting method (Haphazard planting of tubers without land levelling and covering with soil).

- Planting in line on plain wide beds and covered with soil from one side.

- Planting in furrows without ridges.

- Planting in furrows with ridge and finally.

- Planting on top of the ridge. 
The experiment was laid out on a Randomized Complete Block Design with five treatments replicated four times. The row-to-row distance was kept $75 \mathrm{~cm}$, and plantto-plant distance was $20 \mathrm{~cm}$ except in the first case of planting method.

Land was ploughed and well rotten Farm Yard Manure was applied at the rate of 8 tonnes/ha. Recommended dose of fertilizers was used. However half of the dose of Nitrogen was used during land preparation and half of the dose was applied during earthing-up. Whole tubers were used as seed. Disease free seeds were obtained from NIBGE Faisalabad. The crop was sown on 20th May 2005 and harvested in mid-September. The plots in each replication were regularly observed and data was recorded on percent emergence, plant height, plant spread, number of stems per plant, number of tubers per plant, number of green potatoes, injured or damaged potatoes percentage and finally yield per hectare was then calculated. The data were statistically analyzed according to the procedure as described by [23].

\section{RESULTS AND DISCUSSION}

The results of various parameters obtained from the study are discussed as follow, whereas relevant data is given in Table 1.

\subsection{Percent Emergence}

Significant variations were observed in percent emergence and growth of the plants, apparently caused by different sowing methods as the data showed. Maximum percent emergence $(88.7 \%)$ was observed in potatoes planted on plain land covered with soil from one side, while the minimum emergence (54.9\%) was observed in potatoes planted in furrows without ridges.

Maximum emergence percentage in potatoes planted on plain soil covered with soil from one side, may be due to the fact that method provided favourable environment i.e., optimum water and temperature to the tubers for germination, while on the other hand potato tubers planted in furrows without ridges show no satisfactory results because of the lowest germination. It could be due to the less available soil for their growth and development. In some cases potato tubers planted in furrows without ridge were rotten, and it could be due to standing water when irrigated leading to less emergence, growth and production in this very case. Reference [24] mentioned the importance of irrigation water and potato tubers emergence.

\subsection{Plant Height (cm)}

Plant height was significantly different across the tubers sown on different methods. Tubers planted on top of the ridge reached the highest plant height $(53.4 \mathrm{~cm})$ while tubers planted following local farmer's method attained the lowest plant height $(37.5 \mathrm{~cm})$. It might be due to the fact that tuber planted on top of the ridge were covered only with a thin layer of soil, thus these tubers emerged quickly and attained the highest stem height, while on the other hand potato tubers planted in furrows with ridge had a comparatively thick layer of soil and their shoots had to emerge from a thick soil before they could emerge and attain the suitable stem height.

\subsection{Plant Spread (cm) after 60 Days}

The data analyzed for plant spread after 60 days of planting showed that maximum plant spread $(45.5 \mathrm{~cm})$ was recorded in tuber planted on plain wide beds and covered with soil from one side. One reason may be due to earthing-up, which provided enough nutrients in the roots zone of the plants and also due to the favourable environment that this method provided to the plants leading to good emergence and healthier plants. On the other hand potato tubers planted following the local farmers method, showed poor plant spread $(29.9 \mathrm{~cm})$. It might be due to poor emergence, weaker plants less nutrients and water available to all the plants due to hap-

Table 1. Effect of potato cv. Desiree to different sowing methods at Kaghan Valley.

\begin{tabular}{|c|c|c|c|c|c|c|c|c|}
\hline $\begin{array}{l}\text { Sowing } \\
\text { methods }\end{array}$ & $\begin{array}{l}\text { Percent } \\
\text { emergence }\end{array}$ & $\begin{array}{l}\text { Pt. height } \\
\text { (cm) }\end{array}$ & $\begin{array}{l}\text { Pt. spread } \\
(\mathrm{cm})\end{array}$ & No. of stems/plant $\Gamma$ & No. of tubers/plant & $\begin{array}{l}\text { No. of } \\
\text { green tubers }\end{array}$ & Damaged tubers \% age & Yield t/ha \\
\hline 1 & 64.9C & $37.5 \mathrm{E}$ & 29.9E & 1.9D & $5.8 \mathrm{D}$ & $12.5 \mathrm{~A}$ & $5.3 \mathrm{~A}$ & $3.5 \mathrm{D}$ \\
\hline 2 & $88.7 \mathrm{~A}$ & 50.9B & $45.5 \mathrm{~A}$ & $3.5 \mathrm{~A}$ & $10.1 \mathrm{~A}$ & 8.3B & $2.8 \mathrm{D}$ & $12.4 \mathrm{~A}$ \\
\hline 3 & $54.9 \mathrm{D}$ & $43.8 \mathrm{D}$ & $40.8 \mathrm{~B}$ & $2.9 \mathrm{C}$ & $6.7 \mathrm{C}$ & $5.5 \mathrm{C}$ & $3.1 \mathrm{C}$ & $6.2 \mathrm{C}$ \\
\hline 4 & 82.8B & 48.9C & $34.0 \mathrm{D}$ & 3.3B & $9.5 \mathrm{AB}$ & $5.0 \mathrm{C}$ & $3.1 \mathrm{C}$ & $11.6 \mathrm{~A}$ \\
\hline 5 & 80.3B & $53.4 \mathrm{~A}$ & $38.9 \mathrm{C}$ & 3.3B & $7.2 \mathrm{BC}$ & 9.3B & 3.7B & 8.3B \\
\hline LSD at 0.05 & 5.8 & 1.44 & 1.03 & 0.12 & 0.64 & 1.29 & 0.68 & 1.21 \\
\hline
\end{tabular}

Explanation of the first column: 1) Local farmer’s planting method (haphazard planting of tubers on plain soil covered with soil from all the sides); 2) Planting on plain wide beds and covered with soil from one side; 3) Planting in furrows without ridge; 4) Planting in furrows with ridge; 5) Planting on top of the ridge. 
hazard plantation. And as no earthing-up was practiced in this method, therefore some plants fill down due to less support and bare roots on soil surface. Reference [10] mentioned about the proper planting methods and its impact on potato tuber production. Similarly reference [11] found that sufficient and efficient supply of nutrients to the root zone of potato plants via best planting method is important for optimum growth and yield of potato crop.

\subsection{Number of Stems per Plant}

Our data analysis showed that minimum number of stems per plant (1.9) was recorded in plants planted haphazard on unlevelled land, followed by tubers when planted in furrows without ridges. Potato planted on plain wide beds and covered from one side gave maximum number of stems per plant (3.5). It may be due to aeration and earthing-up that were provided to the tubers in this planting system. This parameter is of great importance because it is directly related with the total production of tubers. The more is the number of stems/plant the more will be the number of tubers per plant. Number of stems per plant is also important for tuber size. Less number of stems per plant had tubers of large size and vice versa. This parameter is primarily recorded to see the impact of total sun shine received as well as spread of the root system of the plant. Both these parameters are maximum if there is more number of stem per plant, extending the plant spread.

\subsection{Number of Tubers per Plant}

Data in Table 1 shows that number of tuber per plant was significantly different in plants sown with different planting methods. The maximum number of tubers (10.1), followed by (9.5) was observed when tubers were planted on plain wide beds and covered with soil from one side followed by planted in furrows with ridges. It may be due to supply of adequate amount of water, more aeration and earthing-up, while on the contrary, number of tubers per plant was minimum (5.8) when tubers were planted haphazard on un-level land i.e., following local farmers methodology. It might be due to more soil and nutrients erosion and less water availability to the plants when it was required. Reference [14] found similar findings while working on the effect of in-row spacing and seed type on the yield of potato crop and [22] discussed the details of fertility level available in different sowing method of potato crop.

\subsection{Number of Green Potato Tubers}

The data presented in Table 1 reveal that number of green tubers was significantly different in different sow- ing methods. Local farmer's planting method gave maximum green tubers (12.5), followed by (9.3) when tubers planted on top of the ridges. The best results with less number of green tubers (5.0) were observed in sowing the tubers in line on wide plain beds. It might be due to the effect of ample soil on top of the roots preventing the tubers from direct sunlight and in this way protect in from greening and sun burning. The results coincide with the findings of [25], who reported that ridging significantly improved yield and reduced tuber greening.

\subsection{Injured/Damaged Potato Percentage}

The data regarding damaged potato percentage showed significant differences influenced by different sowing methods. Its percentage was maximum (5.3) when tubers were planted following local farmer's method, may be due plants were not in rows but haphazard, which increased the chance to injure potatoes during harvesting. On the other hand potato tubers planted in lines on plain wide beds in rows and covered with soil from one side produced less damaged tubers (2.8). This method also facilitated us in harvesting with less damage to tubers by harvesting implements.

\subsection{Yield per Hectare (t/ha)}

The data regarding this parameter was also signifycant across the sowing methods. Planting on plain wide beds in lines covered from one side produced maximum tuber yield per hectare (12.4 t/ha). It may be due to the reasons of good emergence, excellent plant spread and more number of stems per plant. Due to good plant spread, more area was exposed to sunlight. It increased photosynthesis and thus increased starch accumulation, which led to high yield. It may also be due to the effect of earthing-up as it provides sufficiently loose soil for adequate drainage and aeration. Aeration of the soil has a great effect on tubers setting and development while potato tubers planted haphazard on sloppy land (local farmers method) showed poor results because the soil and nutrients were eroded leaving the plants root bear and less fertile soil. These results are in agreement with the findings of other studies worldwide [22,26,27].

\section{CONCLUSION AND RECOMMENDATIONS}

This study was conducted to evaluate five different planting systems for potato production in Kaghan valley. We found that planting potatoes in plain wide beds may improve water and nitrogen use efficiency due to a reduction in the amount of infiltration in the furrow, beyond the extent of much of the potato root zone. Our recommended planting system provide a new opportunity to manipulate plant spacing to maximize use of 
available water and nutrient resources as well as target specific potato markets based on tuber size. Optimum plant population is likely a key issue to be resolved in order to make wide bed planting systems economically advantageous relative to local farmers planting system. Additional research on soil water and nutrients dynamics in different planting system is however required to fully exploit potential increases in water and nutrients use efficiency.

\section{REFERENCES}

[1] FAO (1986) Agricultural production yearbook. FAO Statistics Series, 36, 126-127.

[2] Gandapur, A.K. (1995) Evaluation of potato varieties in Hazara. M.Sc. (Hons) Thesis, Department of Plant Breeding and Genetics, NWFP Agricultural University, Peshawar.

[3] Woolfe, J.A. (1987) The potato in the human diet. Cambridge University Press, Cambridge, 231.

[4] Horton, D. (1987) Potatoes: Production, marketing, and programs for developing countries. Westview Press, Colorado, 244.

[5] Ivins, J.D. and Milthope, F.L. (1963) The growth of potatoes. Butterwoyhs, London, 328.

[6] Maikhuri, R.K., Rao, K.S. and Saxena, K.G. (1996) Traditional crop diversity for sustainable development of central Himalayan agroecosystems. International Journal of Sustainable Development \& World Ecology, 3, 831. doi:10.1080/13504509609469926

[7] Van Der Zaag, D. and Horton, D. (1983) Potato production and utilization in world perspective with special reference to the tropics and sub-tropics. Potato Research, 26, 323-362. doi:10.1007/BF02356154

[8] Agricultural Statistics of Pakistan (2004-2005) Ministry of food agriculture and livestock, food and agriculture division. Economic Wing, Islamabad.

[9] Shekkawat, G.S., Paulkhurana, S.M., Pandey, S.K. and Chandla, V.K. (1994) Potato present and future. Indian Potato Association, Shimla, 113-114.

[10] Ali, A. and Wright, D.J. (2011) Multitrophic interactions in aphids potato system. Ph.D. Thesis, Imperial College, London, 221.

[11] King, B.A., Tarkalson, D.D., Bjorneberg, D.L. and Taberna Jr., J.P. (2011) Planting system effect on yield response of russet norkotah to irrigation and nitrogen under high intensity sprinkler irrigation. American Journal of Potato Research, 88, 121-134. doi:10.1007/s12230-010-9169-9

[12] Tarkalson, D.D., King, B.A., Bjorneberg D.L. and Taberna Jr., J.P. (2011) Evaluation of in-row plant spacing and planting configuration for three irrigated potato cultivars. American Journal of Potato Research, 88, 207217.

[13] Essah, S.Y.C. and Honeycutt, C.W. (2004) Tillage and seed-sprouting strategies to improve potato yield and quality in short season climates. American Journal of
Potato Research, 81, 177-186. doi:10.1007/BF02871747

[14] Entz, M.H. and LaCroix, L.J. (1984) The effect of in-row spacing and seedtype on the yield and quality of a potato cultivar. American Potato Journal, 61, 93-105. doi:10.1007/BF02852882

[15] Rabbani, M.G. and Siddique, M.A. (1987) Effect of planting method and mulching on the yield of two sweet potato varities. Department of Horticulture, Bangladesh Agricultural University, Mymensingh, 12, 83-87.

[16] Kim, S.Y., Rvu, O.H. and Hahn, R.H. (1989) The effects of ridging system and planting depth of the growth, yield and saving of labour in polyethylene film mulched spring potato crop. Research Reports of the Rural Development Administration Horticulture, 31, 25-29.

[17] Ekeberg, E. (1990) Direct planting of potatoes. Utredning/Rapport Nordiske Jordbrugsforskeres Forening, 56, 191-196.

[18] Lukyanenko, I.A., Varava, B.V., Shemavan’ov, B.I., Kozar, D.G. and Grekova, N.V. (1990) Effect of planting patterns on tuber yield and econmic efficiency of potato cultivation in the steppe zone under irrigation. Kartoplyarstvo, 21, 42-44.

[19] Lallan, S. and Singh, L. (1992) Use of sprouts fro aphid multiplication in potato. The Indian Journal of Agricultural Sciences, 62, 101-105.

[20] Sharma, S.K. and Dixit, R.S. (1992) Effect of irrigation and planting techniques on tuber yield of potato. Indian Journal of Agronomy, 37, 763-768.

[21] Sharma, S.K., Dixit, R.S. and Tripathi, H.P. (1993) Water management in potato. Indian Journal of Agronomy, 38, 68-73.

[22] Gupta, C.R., Sing, P.N., Shekhawat, G.S., Khurana, S.M. P., Pandey, S.K. and Chandla, V.K. (1994) Effect of method of planting and fertility levels on yield of potato. Potato: Present and Future. Proceedings of the National Symposium, Modipuram, 1-3 March 1993, 113-114.

[23] Gomez, K.A. and Gomez, A.A. (1984) Statistical procedures for agricultural research, 2nd Edition, John Wiley and Sons, New York.

[24] Alva, A.K., Hodges, T., Boydston, R.A. and Collins, H.P. (2002) Effects of irrigation and tillage practices on yield of potato under high production conditions in the Pacific Northwest. Communications in Soil Science Plant Analysis, 33, 1451-1460. doi:10.1081/CSS-120004293

[25] Escobar, G., Zaag, P.V. and Vanderzaag, P. (1988) Field performance of potato (Solanum spp.) cuttings in the warm tropics; imfluence of planting system, hilling, density and pruning. American Potato Journal, 65, 1-10. doi:10.1007/BF02855308

[26] Cooley, E.T., Lowery, B., Kelling, K.A. and Wilner, S. (2007) Water dynamics in drip and overhead sprinkler irrigated potato hills and development of dry zones. Hydrological Processes, 21, 2390-2399. doi:10.1002/hyp.6751

[27] King, B.A., Tarkalson, D.D., Bjorneberg, D.L., Taberna, Jr., J.P. (2010) Planting system effect on yield response of russet norkotah to irrigation and nitrogen under high intensity sprinkler irrigation. American Journal of Potato Research, 2010. 